\title{
ONCIDIUM SURPRISES WITH DEOXYRIBONUCLEIC ACID
}

\author{
HARRY ZELENKO \\ Asociación de Orquideología de Quito and Greater New York Orchid Society \\ P.O. Box 17-22-20043 Cumbaya, Quito, Ecuador \\ zzz@uio.satnet.net
}

There is an armchair taxonomist I know that wrote that the taxonomy of the Oncidium alliance was a mess. I'd been thinking that the remark was based on lack of knowledge. In my opinion, he is way off base. Know that I am not a taxonomist... only a grower and an artist. But I do believe that the Oncidium alliance is a reasonably well organized taxonomy.

My first orchid was purchased from Jones and Scully in 1962. Around 1980 I began growing species in the Oncidium alliance and illustrating the plants and flowers. I have painted actual size portraits of more than 850 plants and flowers in Oncidium as well as other genera. When one paints an orchid flower, it is visually dissected for accurate illustration. This leads to a modicum of knowledge, but I still consider myself an amateur. But what I do know is that botanical taxonomy has taken a turn for the better and has become a scientific, rather than an intuitive, process for classification.

For many years, Norris Williams and Mark Chase have been working with deoxyribonucleic acid or DNA which is the key molecule responsible for defining heredity in plants (as well as in humans) for orchids in the Oncidium alliance; Norris in Gainesville, Florida and Mark at the Jodrell Laboratory at Kew of which he is the head. What they have been finding with molecular sequencing has made for a number of surprises. Their molecular analysis has even moved groups of species from one genus to another.

As an example, the Brazilian monotype we have known for years as Oncidium phymatochilum has been moved into Miltonia based on their studies. The species is now Miltonia phymatochila. This orchid can produce inflorescences with hundreds of gossamer flowers.

Mexicoa gheisbrechtianum, now Oncidium gheisbrechtianum, has now been returned to Oncidium (where it was originally placed) and is a member of a group of Oncidium species from Mexico and Central America.

Another Mexican and Central American species, Amporoa beloglossum, is now in genus Rhyncostele.
Another monotype, Oncidium onustum, was studied by Williams and Chase and with DNA research and other observations, they confirmed that because there were a number of differences with this species, it was removed from the body of Oncidium and it is now called Zelenkoa onusta. They grow on cacti as well as trees in southern Ecuador and northern Peru.

All of these taxonomic relocations were surprises, and when I got over the shock, they were included in the first and second edition of The Pictorial Encyclopedia of Oncidium. The book was edited by Mark Chase. The book cogently presents the major groups in the Oncidium alliance and has been proven useful as a reference book. More surprises have been included with many in the Oncidium alliance moved into new groups, their relationships defined and verified with DNA and included in the book with a DNA tree. With the changes made by Williams and Chase, Oncidium is far from being a "mess" as the book demonstrates.

Here's another surprise: Cyrtochilum, until recently, was generally accepted to cover a group of large-flowered Oncidium. But based on DNA analysis, some groups that were formerly in Oncidium and Odontoglossum have been moved into Cyrtochilum which now includes the species in the groups called Myanthum, Cimiciferum, Ramosissimum, Angustatum, Aureum, and Buesiella, along with the large-flowered Cyrtochlium which, for convenience, we call the Macranthum group. Though separate from Oncidium) they all, of course, remain in the Oncidium alliance.

The large-flowered Cyrtochilum, first described by Kunth in 1815 , was based on the discovery of a plant by Humboldt and Bonpland in Colombia during their Andes exploration around the beginning of the nineteenth century. The plant became the type for a group of about fifty species that are found mostly in the Andes of Venezuela, Colombia, Ecuador, Bolivia and Peru with one species found in the Caribbean. 
In 1990 I met Alex Hirtz in the States and he invited me to the Guayaquil orchid show the following year. I went and I saw a magnificent plant labeled Odontoglossum eduardii. To me, the flowers did not remotely resemble an Odontoglossum. Because the flowers of $O$. eduardii had triangular or shield-shaped lips, they more closely resembled flowers in the Cimiciferum group. Around that time, Carl Withner wrote about the species in the American Orchid Society magazine and they were then still called Odontoglossum. I illustrated two forms of the species and Mark agreed they belonged in Cimiciferum, and so were placed there in the original edition of our book published in 1997. DNA research has since confirmed that this species does belong there. This was a minor surprise... however there were other surprises that I had a hard time accepting when I learned of them. Two groups that, at first, did not seem to me to be anywhere near each other in the Oncidium lexicon were Otoglossum and Globuliferum. Some traditional taxonomists have questioned the findings because, on the surface, they have physical features that seem dissimilar. But I later noted that these orchids also have similar features that bring them closer together. With DNA research, Williams and Chase found that the groups are so closely related genetically that they should be combined into a single genus, as they were.

Another surprise I had a difficult time with was the Erycina genus. The genus now includes Erycina cristagalli along with Erycina pusilla and Erycina glossomystax (formerly both known as Psygmorchis and earlier Oncidium) in addition to Erycina echinata, and Erycina hyalinobulbon. All are twig epiphytes. Erycina cristagali and Erycina pusilla and Erycina glossomystax are very close in many respects. Erycina cristagalli is from Central America while the others are very widespread and occur from Central America to Venezuela, the Guayanas and extend west and south in South America as far as Bolivia. These species usually grow in dappled light with high humidity and are rather softleaved. But Erycina echinata from Mexico grows quite a bit dryer in bright light and its leaf texture feels harder than the former species. Although the floral characteristics for Erycina cristagalli and Erycina psygmorchis are very similar... it is hard to tell the flowers apart... they seemed rather far apart from Erycina echinata, but I was reassured by Norris that their DNA work verified the relationship without question.

Taxonomic tradition, based on intuition combined with knowledge, had usually placed orchids with obviously similar characteristics into groups. The "mule ear" and "rat-tail" oncidium were always treated as separate entities. Their physical differences seemed obvious and this kept them apart. However, molecular analysis has changed this and folded the two groups into genus Trichocentrum.

Another surprise includes a small group of large, widespread, warm-growing plants that can produce large quantities of flowers. Species in this group range from Central America south to Peru and were previously classified as Oncidium. They are now a new genus based on their DNA; Cyrtochiloides, in which there are possibly four species... Cyrtochiloides cardiochila and Cyrtochiloides ochmatochila might be geographic varieties of a single species. There's also Cyrtochiloides riopalenquense and Cyrtochiloides panduriforme. The Ecuadorian species, Cyrtochiloides riopalenquense produces a branched inflorescence that can exceed twelve feet (about four meters) with as many as a hundred flowers.

Williams and Chase also have found that the species in Helcia, Leucohyle and Neoescobaria are members of Trichopilia. Other authors had treated them as species of Trichopilia in the past, so it was not too great a surprise. Their work, however, confirms the definitive relationship of these plants without question in my mind.

Here's another surprise that's easy to live with: The species of Cochlioda and Symphyglossum are considered Oncidium by Mark and will be so listed in the future rather than as separate genera.

Now we come to what had been known for years as Oncidium cucullatum. A small-flowered brown and white orchid first found near Cauca, Colombia and named Caucaea radiata was described years before Oncidium cucullatum. Williams and Chase found that with molecular analysis Caucaea radiata fell right in the center of the species of Caucaea olivaceum they tested (which is the correct name for Oncidium cucullatum). It was another surprise to me because the flowers seemed so different. The well-known taxonomist, John Stacy, listed twenty-two species and varieties related to Oncidium cucullatum in his monograph that was echoed by another renowned taxono- 
mist who had not studied them in the field but produced a retread of Stacy's work in the America Orchid Society magazine. When Stacy visited Ecuador more than thirty years ago, he could not have seen many populations because fewer roads were open then as compared with today. I disagree with Stacy's designation of the number of species and believe that there are far fewer than he claims. Stacy gave species status to a plant with a branched inflorescence, another to one with a straight raceme, and another to one with a zigzag spike, although the flowers of all three are similar. Among the more than fifty Caucaea plants from all over Ecuador and Colombia that I grow, I had one with all three forms of inflorescence on a single plant. Either he was not correct or I have a Caucaea with all three species. Some of the flowers in Caucaea have different lip calli, but according to Mark Chase, this may not define a species. In the Caucaea genus, including olivaceum, I believe that there are only Caucaea sanguinolentum, Caucaea mimetica, Caucaea nubigena and Caucaea phalaenopsis as good species and most of Stacy's "species" names are for geographic varieties. Okay... some of the plants in the group might be different species. We hope to learn more about them one day with DNA analysis.

Stig Dalstrom has researched and written about Odontoglossum and offered the opinion, based on extensive studies, that many of the so-called species are, in reality, geographic varieties. I agree with him.

Odontoglossum harryanum ranges from Colombia to Peru. It was separated from Odontoglossum wyattianum, in part based on the two having different column wings. Stig discovered a harryanum in southern Ecuador with the same column wings as wyattianum. Wyattianum is therefore the southern form of harryanum and is treated in our book as a variety.

I have a hard time thinking of Odontoglossum as being separate from Oncidium. Having grown both genera for more than twenty five years, to me, the differences that have divided them are so minor that I think it possible they will one day be combined. I know that Mark \& Norris also believe this. Years ago, Beer put them all together into Oncidium, so it would be easy to consider them all back there again. DNA findings and not a propensity for "lumping" would be the basis for doing so in my opinion.

There are taxonomists who have produced excellent work over the years that do not agree with the findings of molecular analysis. They question the accuracy of DNA readings. But new science is hard to refute. For me, there's no room for compromise. I have bitten the DNA bullet and have come to believe that this form of classification is here to stay, that is, until something better comes along. But I'll be surprised if that happens.

Harry Zelenko was born in 1928 in New York City. He was trained as an artist at the High School of Music \& Art followed by the Art Student's League and courses in art at New York University. At the age of nineteen he became art director of the largest advertising agency in Connecticut. Zelenko Associates, a creative a design group, was founded in 1953. His work has received many professional awards and he has lectured and exhibited internationally. In New York, he built orchid greenhouses on the roof and terrace of his brownstone where he grew about three thousand orchids. In 1984 he began producing paintings for a book on orchids, and as Z A I Publications, published the first edition of The Pictorial Encyclopedia of Oncidium in 1997 with more than 850 paintings of plants and flowers. The second, revised edition followed seven years later. He moved to Ecuador and built two greenhouses to house a tripled collection of orchids. He is currently a member of the Greater New York Orchid Society and the Quito Orchid Society. 